\title{
PAROKI BERAKAR LINGKUNGAN: MUPAS II DALAM PERSPEKTIF KONSILI DAN PASCAKONSILI VATIKAN II
}

\author{
Petrus Canisius Edi Laksito \\ STKIP Widya Yuwana \\ nanglik@gmail.com
}

\begin{abstract}
The Second Pastoral Consultation of the Diocese of Surabaya held on October 18th-20th 2019 declared the Pastoral Strategic Policy of the Diocese of Surabaya for 2020-2030, formulated in these words: "In the spirit of the Basic Direction, the Catholic Church of the Diocese of Surabaya matures lingkungan rooted parishes present in the middle of the society". This article wants to know in what matters and how strong this Diocese of Surabaya's Pastoral Strategic Policy is connected to the voices of the pastors of the universal Church, especially those echoed in the doctrine of the Second Vatican Council (1962-1965) and that of the subsequent period. It is hoped that such reflection brought a clearer vision and understanding regarding such an important policy, granted that it will lead the faithful people of the Catholic Church of the Diocese of Surabaya in their pilgrimage to God in this world for the next 10 years. By knowing its connectedness with the voices of the pastors of the universal Church, it is expected that the faithful people of the Diocese of Surabaya would be more aware of the voice of Jesus Christ, the Good Pastor, who himself leads his flock to the green pastures of love shared in faith and hope with peoples they enconter.
\end{abstract}

Keywords: Parish, Lingkungan, Basic communities, communion, Diocese of Surabaya

\section{PENDAHULUAN}

Musyawarah Pastoral (Mupas) II Keuskupan Surabaya berlangsung pada 18-20 Oktober 2019 disertai komitmen untuk "menyadari kembali, mendalami, memperkaya, dan menindaklanjuti cita-cita Ardas yang telah dinyatakan dalam MUPAS pertama” (Seri MUPAS Buku 1, 2019: 4). Cita-cita Ardas sendiri berbunyi: “Gereja Katolik Keuskupan Surabaya sebagai persekutuan murid-murid Kristus yang semakin dewasa dalam iman, guyub, penuh pelayanan, dan misioner” (Seri MUPAS Buku 1, 2019: 2). Adapun keinginan untuk menindaklanjuti cita-cita Ardas itu dinyatakan dalam Kebijakan Pastoral 10 tahun ke depan, pada tahun 2020-2030: "Dalam semangat Ardas Gereja Katolik Keuskupan Surabaya mendewasakan Paroki berakar Lingkungan yang hadir di tengah Masyarakat” (Seri MUPAS Buku 1, 2019: 4-5). Di satu sisi Mupas II memperlihatkan keinginan memperdalam pengertian tentang cita-cita Ardas, dan 
di sisi lain menjabarkan pencapaiannya lebih konkret dan terstruktur. Hal ini tampak dari 4 buku Seri Mupas II yang dihasilkan.

Pendalaman pengertian cita-cita Ardas dirumuskan dalam Buku 1, Arah Dasar Keuskupan Surabaya Tahun 2020-2030. Buku ini menjabarkan 5 gagasan teologis kunci pada kalimat cita-cita Ardas, yaitu kemuridan, persekutuan, kedewasaan iman, guyub dan penuh pelayanan serta misioner, ke dalam 48 butir penjelasan. Pendalaman ke dalam 48 butir penjelasan ini berfungsi sebagai rujukan teologis-pastoral bagi implementasi cita-cita Ardas.

Dorongan implementasi dengan sasaran lebih konkret dirumuskan dalam Buku 2, Kebijakan Pastoral Strategis Keuskupan Surabaya Tahun 2020-2030 yang memutuskan pilihan untuk "mendewasakan paroki berakar lingkungan yang hadir di tengah masyarakat”. Sebagai teks yang berbicara tentang "kebijakan”, buku ini tidak membicarakan aspek administratif-managerial, melainkan makna biblis-teologis-filosofis dan strategis "berakar lingkungan yang hadir di tengah masyarakat”. Menggarisbawahi bahwa pilihan ini bersifat fundamental berkenaan dengan hakikat keberadaan dan makna kehadiran Gereja di dunia sekitarnya. Pada bagian akhir ditarik "konsekuensi pastoral", menegaskan pentingnya perubahan paradigma dari pastoral berpusat paroki ke pastoral berakar lingkungan.

Pada Buku 3, Program Strategis Keuskupan Surabaya Tahun 2020-2030, dimuat rencana yang lebih utuh secara pastoral, khususnya di tingkat keuskupan. Mulai dari pendasaran teologis, sosio-pastoral, kemasyarakatan, penataan struktur pastoral tingkat keuskupan hingga lingkungan, sampai penentuan prioritas hal-hal strategis yang ingin dicapai selama 10 tahun ke depan.

Buku 4, Pedoman Pastoral Pengurus Lingkungan Keuskupan Surabaya Tahun 2020-2030, bermaksud mewujudkan keseriusan dalam memperhatikan lingkungan sebagai akar paroki yang hadir di tengah masyarakat dengan memberi perhatian pada dimensi pastoral persekutuan lingkungan. Buku ini menjadi andalan implementasi di lapangan, di tataran pastoral akar rumput.

Dengan lingkup bahasan Mupas II di atas, artikel ini ingin menggali visi dokumen Konsili Vatikan II dan sesudahnya berkaitan dengan kebijakan penting Mupas II untuk "mendewasakan paroki berakar lingkungan yang hadir di tengah masyarakat", yang akan memandu umat Keuskupan Surabaya dalam peziarahan menuju Allah di dunia 10 tahun ke depan. Refleksi berdasarkan ajaran Gereja ini diharapkan membantu melihat dalam hal apa dan sejauh mana gerak pastoral Keuskupan Surabaya sungguh terhubung dengan semangat menggereja yang digemakan oleh para gembala Gereja secara universal. Dengan mengetahui keterhubungan gerak Gereja lokal dengan suara para gembala Gereja universal, diharapkan kita semakin sadar akan suara Yesus sendiri, Gembala yang Baik, yang memimpin kawanannya menuju padang hijau kasih, yang dibagikan dalam iman dan harapan bersama semua orang yang kita jumpai di perjalanan. 
Fokus bahasan artikel ini adalah "paroki berakar lingkungan”. Fokus ini dipilih karena gagasan "paroki berakar lingkungan” merupakan gagasan kunci di balik semangat menjadikan Keuskupan Surabaya sebagai Gereja yang signifikan (berarti dalam dirinya) dan relevan (berkontribusi bagi masyarakat sekitarnya) pada tataran konkret, dengan lebih melibatkan umat pada tingkat akar rumput.

Dokumen Konsili Vatikan II dan sesudahnya setidaknya menyajikan 3 kata kunci yang menerangi fokus ini, yaitu paroki, persekutuan dan komunitas basis. Ketiga kata kunci ini, yang akan akan menerangi fokus refleksi kita tentang paroki, lingkungan dan persekutuan, kiranya dalam lingkup lebih luas meneguhkan dimensi eklesiologis-pastoral Gereja Keuskupan Surabaya.

Untuk itu, artikel ini mula-mula membahas kebijakan strategis pastoral Keuskupan Surabaya hasil Mupas II tahun 2019, “paroki berakar lingkungan”. Lalu dikaji ajaran Gereja dalam Konsili Vatikan II dan pascakonsili terkait dengan tema ini. Mula-mula diulas gagasan tentang paroki dalam dokumen-dokumen Konsili, dilanjutkan dengan penegasan tentang hakikat Gereja sebagai persekutuan, dan komunitas basis sebagai cara baru hidup menggereja, bersumber dari Sinode Luarbiasa Uskup-uskup 1985 serta Seruan Apostolik Paus Paulus VI Evangelii Nuntiandi tahun 1975 yang dirujuk oleh Sinode. Akhirnya dicoba dilihat keterhubungan antara Mupas II dengan gagasan-gagasan Konsili dan pascakonsili, serta relevansinya bagi perwujudan Ardas Keuskupan Surabaya.

\section{PEMBAHASAN}

\subsection{PAROKI BERAKAR LINGKUNGAN: MUPAS II}

Perjalanan karya pastoral Keuskupan Surabaya setelah Mupas I, dari tahun 2009 sampai 2019, diwarnai dengan pilihan berupa "penguatan struktur pastoral Keuskupan, Kevikepan dan Paroki”, berbekal kesadaran akan jati diri Gereja sebagai persekutuan (Seri MUPAS Buku 3, 2019: 8). Upaya mewujudkan Gereja sebagai persekutuan tercermin dalam penataan struktur Keuskupan berdasarkan Pola Pastoral Berbasis Persekutuan yang dicanangkan tahun 2008, dan perumusan Arah Dasar Keuskupan pada Mupas I tahun 2009, yang terkandung dalam kalimat cita-cita "Gereja Keuskupan Surabaya sebagai persekutuan murid-murid Kristus yang semakin dewasa dalam iman, penuh pelayanan dan misioner”.

Sementara, dalam proses itu, sejak tahun 2017, "Uskup menetapkan bahwa rumusan cita-cita Ardas masih sangat relevan untuk diperdalam dan ditindaklanjuti di periode selanjutnya (2020-2030)”. Ketetapan atau kesimpulan itu diperoleh dari kegiatan visitasi pastoral Uskup dan Koordinasi Karya Pastoral (KKP), serta dari evaluasi Dewan Pastoral Keuskupan. Masukan yang sama diperoleh dari Hari Studi Imam dan diskusi pendalaman di KKP (Seri MUPAS Buku 1, 2019: 4). Selanjutnya, melalui rangkaian proses Pra-Mupas II, Uskup menetapkan "pendewasaan Paroki berakar Lingkungan yang hadir di tengah 
masyarakat” dengan semangat Ardas sebagai kebijakan strategis selama dasawarsa kedua masa bakti penggembalaannya (2020-2030).

Dengan kebijakan ini, terlihat adanya semangat kesinambungan untuk mewujudkan Gereja sebagai persekutuan, yang telah diupayakan pada periode sebelumnya. Jika pada periode sebelumnya yang dikuatkan adalah struktur pastoral di tingkat keuskupan dan kevikepan yang menguatkan paroki, kini yang ingin diperkuat adalah lingkungan dan stasi sebagai akar penopang kehidupan iman paroki. Dengan demikian pada periode pastoral selanjutnya implementasi semangat Gereja persekutuan ingin diwujudkan pada "basis perwujudan” yang lebih langsung menyentuh hidup sehari-hari umat, di tingkat akar rumput, yaitu di tingkat lingkungan sebagai basis atau akar paroki. Maka "penguatan akar kehidupan paroki di tengah masyarakat yakni "LINGKUNGAN” dalam bingkai persekutuan ini merupakan kelanjutan fokus pastoral sebelumnya. Dari penguatan di struktur pastoral keuskupan, kevikepan dan paroki ke tataran lingkungan, yang pada tingkatan koordinasi pasti melibatkan wilayah atau stasi.

Untuk memberikan pegangan melangkah, bersama dengan hasil-hasil Mupas II yang lain, Dewan Imam menerbitkan Pedoman Pastoral Pengurus Lingkungan dan diberlakukan sejak 2020. Buku ini diterbitkan sebagai Buku ke-4 Seri Mupas 2019, dan diberlakukan secara ad experimentum selama 2 tahun. Juga, direkomendasikan agar tahun 2023 Dewan Imam menerbitkan revisi atas Pedoman Dasar DPP dan BGKP terbitan tahun 2012, dengan diterangi oleh kebijakan strategis Mupas II (Seri MUPAS Buku 3, 2019: 8).

Pembahasan tentang "Paroki berakar lingkungan yang hadir di tengah masyarakat” sendiri secara intensif berlangsung dalam pertemuan-pertemuan PraMupas II yang melibatkan para pastor paroki. Data-data dihimpun dari pertemuan lingkungan dan visitasi Uskup dengan para ketua lingkungan se-Keuskupan. Hasil masukan dari aneka pertemuan itu dirumuskan ke dalam 2 gagasan pokok: lingkungan sebagai akar paroki dan lingkungan yang hadir di tengah masyarakat. Pastoral diumpamakan seperti orang yang menanam pohon, yang melakukan berbagai upaya agar pohon yang ditanamnya menghasilkan buah. Gereja sendiri dianalogikan sebagai pohon, dengan lingkungan sebagai akar yang sangat penting bagi pertumbuhan pohon, sehingga pohon itu menghasilkan buah berupa kekudusan, perbuatan, sikap, nilai kebaikan, dampak positif, kontribusi positif bagi pembangunan Kerajaan Allah (Seri MUPAS Buku 2, 2019: 5).

Dengan analogi lingkungan sebagai akar paroki, lingkungan dipahami fungsinya sebagai penopang tumbuh tegaknya paroki serta penyerap rahmat keselamatan dan nilai-nilai Kerajaan Allah dalam situasi sosial, politik, ekonomi dan budaya serta suka-duka pengalaman hidup sehari-hari. Dalam lingkungan terdapat warisan iman (depositum fidei) yang dihidupi dan diwariskan terusmenerus melalui keluarga-keluarga sebagai akar lingkungan. Di lingkungan, hal- 
hal baik dipadukan dengan cahaya kebenaran menjadi unsur yang menghidupkan seluruh paroki. Nafas kehidupan lingkungan tampak dalam dinamika rohani yang dihidupi oleh rahmat sakramental. Melalui lingkungan, Gereja menampakkan aspek dinamis, bergerak, mengakar, meluas, berdampak, sehingga parokipun turut tumbuh dan berkembang. Lingkungan yang hidup ini selanjutnya bereproduksi atau berkembang biak ketika anggota semakin bertambah, hingga muncul keharusan membentuk lingkungan baru, yang pada suatu saat kelak, bisa pula menjadi stasi, kuasi-paroki bahkan paroki baru (Seri MUPAS Buku 2, 2019: 10).

Secara lebih normatif, dalam Pedoman Pastoral Pengurus Lingkungan Pasal 4 disebutkan 3 fungsi lingkungan. Pertama, menghidupi dan menghidupkan iman warga lingkungan. Proses ini terjadi dalam kebersamaan para warga sebagai murid-murid Kristus dalam menghidupi 5 aspek hidup menggereja: pewartaan, persekutuan, peribadatan, kesaksian dan pelayanan masyarakat. Kedua, meneguhkan iman dan menopang persekutuan Gereja paroki. Kekuatan paroki sebagai persekutuan terdapat pada keteguhan iman dan kekuatan relasi di antara murid-murid Kristus yang hidupnya saling berdekatan secara teritorial di lingkungan masing-masing, khususnya dalam keluarga-keluarga. Keluarga yang hidup menopang lingkungan, dan lingkungan yang hidup menopang paroki. Ketiga, meresapi dan meresapkan nilai-nilai Injil di tengah masyarakat. Sebagai bagian dari kehidupan masyarakat, lingkungan diutus terlibat di dalamnya dan meresapkan nilai-nilai Injil, sehingga Injil menjadi daya hidup bagi masyarakat di sekitarnya. Hal ini diwujudkan baik melalui pribadi-pribadi maupun sebagai satu persekutuan lingkungan (Seri MUPAS Buku 4, 2019: 17).

Dari pencermatan atas Pedoman terlihat bahwa 3 fungsi lingkungan pada Pasal 4 di atas merupakan penerjemahan dari 3 tujuan lingkungan pada Pasal 3. Tujuan tersebut adalah: pertama, terwujudnya persekutuan iman murid-murid Kristus, sehingga setiap warga saling mengenal secara pribadi, saling memelihara dan menumbuh-kembangkan iman dalam komunitas yang lebih kecil melalui 5 tugas Gereja dalam hidup sehari-hari; kedua, menjadi kekuatan yang meneguhkan dan menopang komunitas paroki yang digembalakan oleh pastor paroki, dengan komunikasi dan pengelolaan hidup menggereja yang lebih efektif dalam komunitas yang lebih kecil; ketiga, terlaksananya perutusan Gereja sebagai garam dan terang, dengan keterlibatannya dalam masyarakat melalui komunitas yang lebih kecil (Seri MUPAS Buku 4, 2019: 16).

Lalu bagaimana Mupas II menjelaskan dinamika lingkungan yang diharapkan, sehingga mampu mewujudkan secara konkret fungsi "menghidupi dan menghidupkan iman warga”, "meneguhkan iman dan menopang persekutuan paroki” dan “meresapi dan meresapkan nilai-nilai Injil di tengah masyarakat”, untuk mencapai 3 tujuan lingkungan? Untuk memahami hal ini lebih baik, kiranya 
perlu dilihat lebih dahulu pengertian lingkungan sebagaimana dipahami atau dirumuskan dalam dokumen Mupas II.

Pedoman Pastoral Pengurus Lingkungan Pasal 1 membahas hakikat lingkungan sebagai berikut. Dikatakan:

"Lingkungan adalah cara hidup menggereja murid-murid Kristus dalam persekutuan teritorial berakar keluarga dengan jumlah tertentu, hidupnya berdekatan, memiliki pengurusnya sendiri, dan menghayati imannya secara mendalam melalui 5 (lima) aspek hidup menggereja: pewartaan, persekutuan, peribadatan, kesaksian, dan pelayanan masyarakat. Persekutuan para murid Kristus ini menjadi bagian dari reksa pastoral paroki.” (Seri MUPAS Buku 4, 2019: 16).

Hal pertama yang perlu segera digarisbawahi di sini adalah ungkapan bahwa lingkungan adalah "cara hidup menggereja”. Itu berarti, lingkungan disikapi pertama-tama sebagai modus essendi, cara berada sesuai dengan jatidiri, sekaligus modus vivendi, cara hidup agar apa yang hakiki pada jatidiri menjadi nyata. Sedangkan kata “menggereja” sebagai “cara hidup” kiranya dijabarkan dalam ungkapan "melalui 5 (lima) aspek hidup menggereja: pewartaan, persekutuan, peribadatan, kesaksian, dan pelayanan masyarakat”. Sebagai "cara hidup”, lingkungan bukanlah sekedar definisi untuk dipahami, tetapi pilihan, strategi, gaya, yang ada pada tataran tindakan, dan tugas untuk dikerjakan dalam 5 aspek secara bersamaan. Dengan demikian lingkungan tidak lagi sekedar menjadi "kata benda” melainkan "kata kerja”. Bukan lagi tentang “apa” itu Gereja, karena hakikat Gereja telah kita terima yaitu persekutuan dalam Allah dan di antara para saudara. Dengan menyebut lingkungan, kita masuk ke dalam tahapan cara hidup, ke tahapan "bagaimana”. Yaitu soal pilihan sikap dan cara agar komunitas iman benar-benar terwujud sebagai persekutuan konkret dan berdampak nyata.

Selanjutnya dinyatakan, lingkungan merupakan cara hidup menggereja murid-murid Kristus “dalam persekutuan teritorial berakar keluarga dalam jumlah tertentu, hidupnya berdekatan, memiliki pengurusnya sendiri”. Ungkapan ini kiranya berbicara tentang karakteristik, ciri-ciri atau kekhasan lingkungan, yang membuatnya menjadi suatu "cara hidup menggereja” yang unik atau tersendiri.

Pertama, lingkungan adalah persekutuan teritorial. Dimensi teritorial atau geografis menjadi pilihan, cara menggereja dan pilihan ini merupakan turunan atau derivat yang konsisten dan selaras dengan prinsip pengorganisasian Gereja universal yang terdiri dari Gereja-gereja partikular atau lokal, terutama berupa keuskupan-keuskupan. Dengan cara yang sama, keuskupan-keuskupan, seperti dinyatakan oleh dokumen-dokumen Konsili, juga terdiri dari paroki-paroki, yang terutama adalah paroki teritorial sebagai cara biasa mengorganisasi keuskupan. 
Kedua, akar lingkungan adalah keluarga. Mupas II sendiri, mengutip Paus Yohanes Paulus II, memahami keluarga sebagai “persekutuan pribadi-pribadi” (communio personarum). Dalam kesadaran bahwa keluarga merupakan “persekutuan”, sungguh disadari pula bahwa yang bersekutu adalah pribadipribadi yang, dalam pemahaman Kristiani, memantulkan citra Allah yang bermartabat. Kembali, keluarga sebagai komunitas pribadi-pribadi didefinisikan dengan "kata kerja”, yaitu "ruang terpenting bagi pengakuan dan pengembangan martabat pribadi manusia untuk mencapai kepenuhannya”. Bagi para warganya, keluarga menjadi Gereja kecil, “Ecclesia domestica”, Gereja rumah tangga.

Dengan gambaran ini, simbolisme lingkungan sebagai "akar” paroki dengan tepat dapat diterapkan dalam memandang peran atau fungsi keluarga, yaitu sebagai “akar” penopang iman bagi anggota-anggotanya, yang menghidupi dan menghidupkan lingkungannya, dan menjadi garam yang meresapkan nilainilai Injil di masyarakat sekitarnya (Seri MUPAS Buku 2, 2019: 10-11).

Ketiga, keanggotaan lingkungan didasari oleh keluarga "dengan jumlah tertentu”, yang "hidupnya berdekatan”. Jumlah tertentu merupakan unsur pokok, yang menggambarkan adanya batasan. Batasan jumlah ini dilengkapi dengan batasan selanjutnya, yaitu "hidup yang berdekatan”.

Kedekatan ini mula-mula tentu bersifat fisik, teritorial atau geografis. Tetapi melihat tujuan lingkungan jelas bahwa kedekatan ini berdimensi sosial, eklesial, personal dan rohani. Pedoman Pastoral Pengurus Lingkungan Pasal 3.1 menyatakan: “Terwujudnya persekutuan iman murid-murid Kristus sehingga setiap warga lingkungan saling mengenal secara pribadi, saling memelihara serta menumbuh-kembangkan iman”. Jumlah tertentu yang hidup berdekatan terkait pula dengan efektivitas, dengan buah-buah kehidupan yang diharapkan dapat lebih nyata wujudnya. Hal ini tampak dalam ungkapan tentang bagaimana hidup menggereja dalam 5 aspeknya dapat terwujud, yaitu "dalam komunitas yang lebih kecil”, “dalam hidup sehari-hari di jaman sekarang”. Demikian pula sebagai penopang paroki, lingkungan dapat digembalakan oleh pastor paroki dengan komunikasi dan pengelolaan yang lebih efektif "dalam komunitas yang lebih kecil”, serta terlibat di masyarakat sebagai garam dan terang masyarakat "melalui komunitas yang lebih kecil” (Seri MUPAS Buku 4, 2019: 16).

Dalam arti ini lingkungan sungguh-sungguh terlihat sebagai suatu "persekutuan keluarga-keluarga (communio familiarum) dan komunitas dasar gerejawi”. Hal ini terjadi karena keluarga mendapat tempat utama dalam lingkungan. Sebagai cara hidup menggereja, lingkungan, ditopang oleh keluargakeluarga, menjadi "keluarga” yang lebih besar, bukan hanya dalam arti biologis, tapi sebagai persekutuan keluarga-keluarga yang berakar pada pribadi-pribadi. Di lingkungan para anggotanya membangun semangat kekeluargaan, dan tumbuh bersama sebagai satu keluarga Allah (Seri MUPAS Buku 2, 2019: 11). 
Terkait dengan gagasan lingkungan sebagai “komunitas dasar gerejawi” di atas, selanjutnya dikatakan: "Lingkungan juga dapat kita sebut sebagai Komunitas Dasar Gerejawi (Basic Ecclesial Community) karena Lingkungan ini adalah sel dasar (di atas/sesudah keluarga) dimana gen hidup Gereja secara lengkap tercermin dan terwujud secara konkret” (Seri MUPAS Buku 2, 2019: 12). Pernyataan bahwa lingkungan adalah "sel dasar" “di atas/sesudah keluarga”, dan bahwa di dalamnya "gen hidup Gereja secara lengkap tercermin dan terwujud secara konkret” jelas mengungkap hal yang hakiki. Jejak genetik atau asali Gereja secara nyata hidup dan ditemukan dalam lingkungan. Jika berbicara mengenai Gereja sebagai sakramen atau tanda dan sarana keselamatan dalam Kristus, maka sakramentalitas ini secara utuh dan nyata dijumpai dalam lingkungan.

Keempat, lingkungan menjadi bagian dari reksa pastoral paroki. Sebagai “cara hidup menggereja”, lingkungan bukanlah sejenis kelompok arisan, yang dibentuk berdasarkan "pilihan suka-suka” atas dasar minat, selera atau kemauan anggotanya. Lingkungan adalah “cara hidup menggereja-nya Gereja”. Artinya, cara hidup Gereja itu sendiri sebagai subjek yang hendak mewujudkan jatidiri dan panggilannya sebagai Gereja. Jika Gereja partikular dan kemudian paroki menjadi ungkapan dan cara hidup Gereja universal, demikian pula lingkungan menjadi cara hidup Gereja lokal, khususnya dalam perannya sebagai akar paroki.

Pedoman Pastoral Pengurus Lingkungan Pasal 4.3, yang berbicara tentang fungsi lingkungan, ditutup dengan pernyataan: "Untuk menjalankan ke 3 fungsi itu Lingkungan harus mendapatkan pendampingan pastor paroki beserta Dewan Pastoral Paroki” (Seri MUPAS Buku 4, 2019: 17). Pernyataan ini kiranya dapat dimaknai sebagai penegasan tentang eklesialitas lingkungan. Bahwa lingkungan dari semula keberadaaannya adalah bagian utuh Gereja, berhakikat gerejawi, khususnya sebagai persekutuan keluarga-keluarga dalam paroki. Maka merupakan keharusan pula bahwa lingkungan mendapatkan pendampingan dari gembalanya sendiri, yaitu pastor paroki, dan dari seluruh perangkat pastoral paroki.

Definisi di atas menyatakan, lingkungan "memiliki pengurusnya sendiri" (Seri MUPAS Buku 4, 2019: 16). Dengan adanya suatu kepengurusan sendiri, dapat dimaknai bahwa lingkungan merupakan suatu satuan yang mandiri, sehingga bisa dan harus mampu mengurus dirinya sendiri. Dengan prinsip ini, kebutuhan maupun tugasnya yang meliputi 5 aspek hidup menggereja (pewartaan, peribadatan, persaudaraan, kesaksian iman dan pelayanan) pertama-tama menjadi kebutuhan yang harus dipenuhi dan tugas yang harus dilaksanakan. Tugas ini dilaksanakan dengan partisipasi aktif para warga, juga dengan peran pengurus, pelayan dan pelaksana secara administratif, fungsional maupun koordinatif.

Tetapi kemandirian lingkungan bukanlah kemandirian yang memisahkan lingkungan dari dinamika paroki. Justru dengan kemandirian itulah lingkungan “mengekspresikan” paroki sebagai realitas persekutuan, dalam hidup bersama 
dengan lingkungan-lingkungan lain dalam kesatuan pastoral dengan pastor paroki, dan dalam pendampingan pastor paroki dan dewan pastoralnya di tingkat paroki.

Keberadaan lingkungan-lingkungan dalam paroki, yang di satu sisi menopang paroki dan di sisi lain mendapatkan pendampingan pastoral dari pastor paroki beserta Dewan Pastoral Paroki, menegaskan bahwa paroki itu sendiri adalah persekutuan komunitas-komunitas lingkungan (communio communitatum; communion of communities). Maka yang disebut "paroki” bukanlah sesuatu yang lain di luar lingkungan atau di atasnya. Atau sebaliknya, yang disebut “lingkungan” bukanlah sesuatu yang lain, berbeda dan di tidak terhubung dengan paroki. Keberadaan lingkungan sebagai bagian utuh paroki dan keberadaan paroki sebagai persekutuan komunitas-komunitas ini tidak boleh hanya dimengerti pada tataran konsep atau gagasan belaka, tetapi selalu pada tingkat konkret, di dalam program. "Paroki bukanlah persekutuan tersendiri diluar persekutuan lingkungan. Seluruh program pastoral paroki tidak bisa sebagai kegiatan lain di luar penggembalaan warga Lingkungan. Paroki adalah kesatuan dari lingkunganlingkungan; communion of communities” (Seri MUPAS Buku 4, 2019: 17).

Pada akhirnya, aspek lain lingkungan sebagai komunitas akar paroki terungkap lewat Pedoman Pastoral Pengurus Lingkungan Pasal 2, yang berbicara tentang warga lingkungan. Dikatakan:

"Warga Lingkungan adalah setiap orang Katolik dan calon Katolik, yang berdomisili dalam teritorial lingkungan selama lebih dari 3 bulan. Mereka mendapatkan dan mengalami kasih penggembalaan dari pengurus lingkungan agar bertumbuh imannya melalui 5 (lima) aspek hidup menggereja: perwartaan, persekutuan, peribadatan, kesaksian dan pelayanan masyarakat. Karena Baptis, setiap warga lingkungan dipanggil semakin menjadi saudara-saudara seiman satu sama lain, bersedia dengan tulus melibatkan diri dalam kegiatan-kegiatan yang diselenggarakan di lingkungannya serta terbuka menerima siapa pun sebagai saudara.” (Seri MUPAS Buku 4, 2019: 16).

Lingkungan adalah suatu kehidupan rohani, persekutuan berdimensi ilahi, realitas iman, “cara hidup” berakar pada persekutuan Allah Tritunggal karena dimensi sakramental yang dimiliki oleh warganya melalui Baptis. Karena Baptis, mereka terpanggil untuk berhimpun, bersekutu dalam ibadat dan pewartaan di antara mereka, dan menjalankan tugas perutusan untuk terlibat dalam kehidupan sesama melalui pelayanan dan kesaksian iman.

Dalam lingkungan yang tampil dan dialami sebagai Keluarga Allah ini terungkap eksklusivitas berdasarkan Baptis. Tidak setiap orang bisa tergabung atau terhitung sebagai warga. Tetapi berdasarkan Baptis itu pula terdapat dimensi inklusivitas, keterbukaan. Selain setiap orang Katolik, yang juga termasuk warga 
lingkungan adalah para calon Katolik. Baptis yang telah diterima maupun akan diterima memanggil semua untuk "semakin menjadi saudara-saudara seiman satu sama lain”. Dalam persaudaraan baru ini, setiap warga lingkungan "bersedia dengan tulus melibatkan diri dalam kegiatan-kegiatan yang diselenggarakan di lingkungannya serta terbuka menerima siapa pun sebagai saudara”.

Selanjutnya inklusivitas kian nyata karena lingkungan secara khas diutus untuk hadir di tengah masyarakat. Bukan sebagai suatu kehadiran yang bersifat aksesoris, hanya hiasan, sebab inklusivitas dalam bingkai kemasyarakatan ini berakar pada dimensi misioner dan sakramental Gereja yang tertera pada lingkungan sebagai komunitas basis, akar paroki. Sebagai tanda dan sarana persekutuan dengan paroki, lingkungan menjadi ungkapan kesatuan inklusif dengan Gereja universal, tetapi juga mampu “memberi kesaksian iman yang hidup di tengah masyarakat (kontekstual). Karena itu, lingkup teritorial tertentu itu menjadi konsekuensi terwujudnya persekutuan manusiawi yang konkret, terbuka, dan bersaksi di tengah masyarakat” (Seri MUPAS Buku 2, 2019: 16).

Sumber inklusivitas terhadap masyarakat adalah Baptis. "Melalui dan oleh rahmat baptis, setiap warga Katolik diutus sebagai saksi Kristus dengan menjadi garam dan terang bagi dunia (masyarakat)”. Baptis sebagai rahmat yang sifatnya personal, dalam lingkungan ditransformasi menjadi tugas komunal, mengubah murid menjadi makluk sosial-eklesial, yang mengemban tugas perutusan bersama sebagai satu persekutuan. Dikatakan: “...lingkungan sebagai persekutuan muridmurid Kristus selalu berjuang meresapi dan meresapkan nilai-nilai Injil bagi masyarakat di sekitarnya. Lingkungan juga sekaligus engsel hidup antara persekutuan Paroki dan keragaman masyarakat. Di dalam dan melalui lingkungan, paroki hadir di tengah masyarakat.” (Seri MUPAS Buku 2, 2019: 17).

\subsection{KONSILI VATIKAN II: PAROKI, KOMUNITAS YANG HIDUP}

Dokumen pertama Konsili Vatikan II, Sacrosanctum Concilium (SC), yang diundangkan pada 3 Desember 1963, antara lain berbincang tentang pentingnya membina kehidupan liturgi di keuskupan dan paroki (SC 41-42). Dikatakan bahwa uskup merupakan "imam agung (sacerdos magnus) kawanannya”. Dengan cara tertentu, darinyalah kehidupan dalam Kristus bagi umat beriman bersumber dan tergantung (derivatur et pendet). Maka kehidupan liturgi di sekitar uskup, terutama di gereja katedral, perlu mendapat penghargaan amat besar. Tetapi karena uskup tidak dapat selalu dan di mana-mana memimpin sendiri seluruh kawanannya, maka ia harus membentuk kelompok-kelompok umat beriman (coetus fidelium) yang lebih kecil (AAS 56, 196: 111-112).

Di antara kelompok-kelompok itu yang terpenting (eminent) adalah paroki-paroki, yang dibentuk berdasarkan lokalitas (localiter ordinatae) dan dipimpin oleh pastor yang berperan sebagai pengganti (vices) uskup. Paroki- 
paroki dikatakan “terpenting” di antara kelompok-kelompok umat beriman yang dibentuk oleh uskup karena paroki-paroki dalam arti tertentu menghadirkan (repraesentant) Gereja yang kelihatan, yang hadir di seluruh muka bumi (per orbem terrarum constitutam). Karena alasan teologis itu pula maka kehidupan liturgi paroki serta hubungannya dengan uskup perlu dipupuk dalam hati dan tindakan (in mente et praxi) umat dan klerus. Juga perlu diupayakan agar semangat persekutuan paroki (sensus communitatis paroecialis) berkembang, terutama dalam perayaan misa bersama hari Minggu (AAS 56, 196: 112).

Selain menegaskan hakikat paroki sebagai kelompok umat beriman yang khas, dengan pernyataan di atas SC juga berbicara tentang fungsi atau nilai penting paroki di tingkat keuskupan sebagai cara yang harus ditempuh uskup agar dapat memimpin seluruh jemaatnya. Sekaligus ditegaskan fungsi lebih jauh dan khas paroki bagi Gereja universal, yaitu fungsi representasi, atau fungsi menghadirkan dan mewakili segenap kenyataan dan kekayaan yang terkandung dalam Gereja semesta yang hadir secara utuh di seluruh dunia. Tentulah fungsi ini tidak bersumber dan bergantung dari paroki itu sendiri ataupun dari umat beriman dan klerus di paroki, melainkan bersumber dan bergantung dari hubungan yang tak terpisahkan dengan uskup, “imam agung” darinya umat beriman mendapatkan kehidupan dalam Kristus. Atas dasar hakikat dan fungsi paroki ini serta hubungannya yang tak terpisahkan dengan uskup, kehidupan liturgi dan hubungan dengan uskup perlu dipupuk dalam hati dan tindakan umat serta pastor paroki.

Dengan gambaran di atas, paroki sebagai kelompok umat (coetus) tidak hanya bersifat statis tetapi dinamis dan hidup, terlebih karena paroki merupakan suatu komunitas yang dibangun di atas dasar semangat persekutuan (sensus communitatis paroecialis) untuk menghadirkan Gereja semesta dalam lokalitasnya. Aspek dinamis paroki ini, yang digerakkan oleh semangat persekutuan paroki, dikembangkan dalam ikatan hati dengan uskup dan diwujudkan dalam pelbagai tindakan umat beriman maupun pastor paroki. Dalam upaya dinamis ini, Ekaristi Hari Minggu yang dirayakan bersama-sama ditempatkan sebagai bentuk kegiatan utama.

Dengan penjelasan di atas sekaligus terlihat bahwa dinamika kehidupan yang berlangsung di paroki tidak melulu bersifat lahiriah saja atau sebaliknya batiniah belaka, tetapi meliputi kedua sisi itu, baik lahiriah maupun batiniah. Dinamika ini merupakan dinamika yang dipupuk dalam hati dan diwujudkan dalam tindakan (in mente et praxi). Dinamika ini berkenaan dengan kehidupan konkret sehari-hari, tetapi pusat dan sumbernya adalah daya ilahi yang diterima bersama dalam Ekaristi. Di sini, dengan demikian, penting digarisbawahi “multidimensionalitas” yang mewarnai realitas kehidupan Gereja yang hidup, yang terwujud dalam paroki dalam fungsi representasinya. 
Dalam khasanah dokumen Konsili, aspek dinamis kehidupan paroki juga dibicarakan di tempat lain, misalnya dalam Konstitusi Dogmatik tentang Gereja Lumen Gentium (LG). Meskipun tidak secara eksplisit menggunakan kata "paroki”, LG 26, dalam rangka tugas uskup sebagai "pengurus rahmat imamat tertinggi" (oeconomus gratiae supremi sacerdotii), berbicara mengenai "jemaatjemaat umat beriman setempat” (fidelium congregationibus localibus) yang sungguh-sungguh menghadirkan Gereja Kristus. Uskup disebut sebagai pengurus rahmat imamat tertinggi terutama dalam Ekaristi, “yang dipersembahkannya sendiri atau yang dipersembahkan atas kehendaknya, dan yang tiada hentinya menghidupkan dan menumbuhkan Gereja”. Dalam Ekaristi, sebagai daya hidup dan pertumbuhan Gereja yang dipersembahkan oleh para pastor yang ditugaskan oleh uskup di paroki-paroki tersebut, Gereja hadir, hidup dan berkembang di dunia. Dikatakan: “Gereja Kristus ini sungguh hadir dalam semua jemaat beriman setempat yang sah, yang mematuhi para gembala mereka, dan dalam Perjanjian Baru disebut Gereja” (AAS 57, 1965: 31).

Berkenaan dengan kehidupan "di masing-masing persekutuan umat beriman setempat" (in singulis localibus fidelium congregationibus) atau dengan kata lain di paroki-paroki, LG 28 berbicara secara khusus mengenai peran para imam. Di paroki-paroki tersebut para imam, yang bersama uskup mereka merupakan satu presbyterium (dewan imam), dalam arti tertentu menghadirkan uskup. Tentang peran tersebut selanjutnya dikatakan: "Mereka ikut mengemban tugas serta keprihatinan Uskup dan ikut menunaikannya dengan ketekunan setiap hari. Di bawah kewibawaan Uskup para imam menguduskan dan membimbing bagian kawanan Tuhan yang diserahkan kepada mereka. Mereka menampilkan Gereja semesta di tempat mereka, dan mereka memberi sumbangan sungguh berarti dalam membangun seluruh tubuh Kristus (lih. Ef 4:12)”. Dengan demikian, selain Ekaristi yang dirayakan bersama oleh umat beriman, imam atau pastor paroki sendiri dalam persekutuan ekaristis dengan seluruh umat menjadi unsur penting lain dan tak terpisahkan dalam tugas paroki menghadirkan Gereja semesta di dalam lokalitasnya (AAS 57, 1965: 35).

Konsili berbicara lebih lanjut tentang pastor yang bertugas di paroki dalam dekrit tentang tugas pastoral uskup Christus Dominus (CD), khususnya dalam CD 28-32 yang membahas imam diosesan (clerus diocesanus). Imam diosesan diinkardinasikan atau ditautkan pada Gereja partikular keuskupan dan sepenuhnya mengabdikan diri untuk menggembalakan bagian tertentu kawanan Kristus (ad unam dominici gregis portionem pascendam). Karena itu mereka membentuk satu presbyterium dan satu keluarga, dengan uskup sebagai bapanya (AAS 58, 1966: 687). Dari antara para imam diosesan ini, para imam yang bertugas di paroki mempunyai kedudukan amat khas selaku rekan sekerja uskup, karena reksa jiwajiwa (cura animarum) di bagian tertentu keuskupan dipercayakan di bawah 
wewenang mereka selaku gembala yang khas dan sesungguhnya bagi umat paroki (pastoribus propriis) (AAS 58, 1966: 688).

Dalam konteks kedudukan khas ini, lagi-lagi digarisbawahi pentingnya peran pastor paroki bagi upaya membangun paroki menjadi suatu komunitas yang hidup, yang memiliki kesadaran diri sebagai representasi yang menghadirkan keuskupan dan Gereja universal dalam lokalitasnya. CD 30 menjelaskan: "Dalam menjalankan reksa pastoral itu hendaklah pastor paroki bersama dengan para pembantunya menunaikan tugas mengajar, menguduskan dan memimpin (munus docendi, sanctificandi et regendi) sedemikian rupa, sehingga umat beriman (fideles) dan jemaat-jemaat paroki (communitates paroeciales) sungguh menyadari diri sebagai anggota keuskupan maupun seluruh Gereja semesta (tum diocesis tum totius Ecclesiae universalis membra)" (AAS 58, 1966: 688).

Di sisi lain, peran membangun paroki sebagai persekutuan yang hidup tidak hanya menjadi tugas gembala. Berkenaan dengan tugas awam untuk ambil bagian dalam tritugas Kristus sebagai imam, nabi dan raja, dekrit Konsili Vatikan II tentang kerasulan awam Apostolicam Actuositatem (AA) berbicara tentang komunitas-komunitas gerejawi (communitates ecclesiae) sebagai bidang perhatian pertama. AA 10 menyatakan bahwa kegiatan awam dalam komunitas-komunitas ini demikian perlu (tam necessaria) sehingga tanpa kegiatan itu kerasulan para gembala sendiri kebanyakan tidak membuahkan hasil sepenuhnya. "Sebab seperti kaum pria dan wanita, yang membantu Paulus dalam pewartaan Injil (lih. Kis 18:18-26; Rom 16:3), begitu pula para awam, yang berjiwa kerasulan sejati, melengkapi apa yang kurang pada saudara-saudara mereka, dan menyegarkan semangat para gembala maupun umat beriman lainnya (lih. 1Kor 16:17-18)” (AAS 58, 1966: 846).

Dinyatakan, sumber peneguhan kerasulan awam di komunitas-komunitas gerejawi adalah partisipasi aktif mereka dalam kehidupan liturgi (actuosa participatione vitae liturgicae suae), dengan itu mereka mengantar orang-orang yang menjauh kembali ke Gereja. Dengan daya peneguhan yang diperoleh dari kehidupan liturgi, mereka mewartakan sabda Allah terutama lewat katekese, serta ambil bagian dalam reksa jiwa-jiwa dan pengelolaan harta milik Gereja.

AA 10 menyatakan, paroki merupakan contoh nyata karya kerasulan dalam komunitas gerejawi, karena paroki menghimpun semua keanekaragaman manusiawi (omnes diversitates humanas) ke dalam satu persekutuan (in unum congregans), dan meletakkannya pada universalitas Gereja (Ecclesiae universalitati inserens). Dalam rangka itu para awam di paroki diharapkan membiasakan diri bekerja dalam persatuan dengan para imam mereka. Mereka diharapkan menyampaikan persoalan mereka sendiri, persoalan masyarakat dan masalah-masalah terkait dengan keselamatan umat manusia, serta mengupayakan bersama pemecahannya. Sedapat mungkin awam menyediakan diri bekerjasama 
bagi upaya-upaya kerasulan dan misioner di paroki sebagai keluarga gerejawi mereka (AAS 58, 1966: 846-847).

Lebih jauh, dengan memandang paroki sebagai semacam sel (velut cellula) keuskupan, para awam juga diharapkan mengembangkan rasa cinta terhadap keuskupan (sensum diocesis). Mereka diharapkan senantiasa bersedia memenuhi undangan uskup selaku gembala mereka untuk menyumbangkan tenaga bagi karya-karya keuskupan. Mereka juga diharapkan mempunyai perhatian lebih luas di lingkup antarparoki, antarkeuskupan, nasional dan internasional. Perluasan perhatian awam ini penting karena ada bermacam-macam kebutuhan yang, karena pelbagai faktor ekologis dan sosial, melampaui batas-batas paroki, keuskupan serta negara (AAS 58, 1966: 847).

Pemahaman paroki sebagai semacam "sel" itu sendiri jelas memberi gambaran tentang nilai penting paroki bagi Gereja, baik keuskupan/Gereja lokal maupun Gereja universal, sebagai suatu organisme yang hidup. Meskipun paroki "hanyalah" bagian suatu tubuh atau organisme yang memiliki keterbatasan dalam lokalitasnya, dan sebagai bagian tubuh tidak dapat hidup sendiri tanpa ikatan dan ketergantungan pada induk yang melahirkannya yaitu keuskupan atau Gereja, paroki tetap bernilai penting (signifikan). Sebagai realitas sosio-pastoral, dengan aneka ragam latarbelakang warga dari pelbagai aspek manusiawinya dan dengan segala permasalahan yang mereka dihadapi dalam keseharian, paroki menjadi tanda sekaligus daya kehidupan yang nyata bagi Gereja keuskupan dan Gereja semesta dalam kehadirannya di dunia. Paroki menjadi sel yang hidup di dalam tugas perutusan Gereja menjadi tanda dan sarana keselamatan bagi umat manusia. Di sini, imam serta awam paroki, sesuai peran mereka, memiliki kontribusi nyata.

\section{PENEGASAN PASCAKONSILI: GEREJA PERSEKUTUAN}

Pandangan Konsili Vatikan II (1962-1965) tentang nilai penting kehidupan paroki sebagai representasi Gereja universal harus diletakkan dalam bingkai pemahaman tentang Gereja sebagai communio/persekutuan. Perspektif ini mendapatkan peneguhan dari Sinode Luarbiasa Uskup-uskup tahun 1985.

Sinode sendiri bertujuan merayakan sekaligus mengevaluasi hasil-hasil Konsili yang berakhir 20 tahun sebelumnya (1965), serta mempelajari secara lebih mendalam ajaran-ajaran Konsili untuk diimplementasikan dalam kehidupan Gereja seiring perkembangan zaman. Dalam Laporan Akhir Sinode, ditegaskan bahwa paham Gereja sebagai Persekutuan merupakan gagasan inti yang terdapat dalam dokumen-dokumen Konsili. Laporan Akhir Sinode bagian C.1 menjelaskan hal itu dengan pernyataan berikut:

"Eklesiologi persekutuan merupakan gagasan sentral dan fundamental dokumen-dokumen Konsili. Koinonia/persekutuan, didasarkan pada Kitab Suci, dipegang penuh hormat di Gereja kuno dan di Gereja-gereja Timur hingga sekarang. Dengan 
demikian, Konsili Vatikan II sungguh berupaya agar Gereja sebagai persekutuan dapat lebih jelas dipahami dan lebih konkret diwujudkan dalam kehidupan” (Extraordinary Synod, 1985).

Dalam Laporan Akhir Sinode C.2 Sinode menggarisbawahi aspek penting communio pada tataran universal dengan membahas hubungan antara persatuan (unity) dan keberagaman bentuk (pluriformity) dalam Gereja. Persatuan Gereja dan keunikannya didasari oleh iman akan satu Allah, akan Yesus satu-satunya pengantara dalam satu Roh, ditandai dengan satu baptisan dan satu Ekaristi. Persatuan, yang menyangkut pula persatuan dengan paus dan para penggantinya, menjadi tanda nabiah bagi persatuan eskatologis yang lebih penuh di akhir zaman. Di sisi lain, Karena Roh yang satu dan sama bekerja dalam Gereja dengan aneka karunia rohani dan kharisma, dan dengan itu Ekaristi yang satu dirayakan di pelbagai tempat di seluruh dunia, maka Gereja semesta sungguh-sungguh hadir dan dapat dijumpai dalam Gereja-gereja partikular (Extraordinary Synod, 1985).

Selanjutnya dalam rangka mewujudkan persekutuan dalam kehidupan Gereja partikular/keuskupan sendiri, Laporan Akhir Sinode C.6 menyatakan: “Karena Gereja merupakan persekutuan, harus ada partisipasi dan tanggungjawab bersama (participation and co-responsability) di semua jenjangnya. Prinsip umum ini harus dimengerti dalam beraneka cara di berbagai area”.

Dalam rangka partisipasi dan tanggung jawab bersama yang harus terwujud di semua jenjang kehidupan Gereja atas dasar hakikat Gereja sebagai persekutuan, seturut LG 28, Laporan Akhir Sinode C.6 berbicara tentang para imam paroki. Para imam dalam cara tertentu menghadirkan uskup di setiap jemaat lokal umat beriman, dan menjalankan tugas-tugas dan keprihatinan uskup lewat pekerjaan harian mereka. Sementara, para uskup sendiri merasakan dengan penuh syukur keterkaitan diri dengan imam-imam mereka, yang menjalankan peran penting dalam menerapkan hasil-hasil Konsili. Mereka ingin dekat pada para imam mereka untuk membantu dan mendukung mereka dalam karya yang seringkali sulit, khususnya di paroki-paroki (Extraordinary Synod, 1985).

Setelah menyinggung partisipasi dan kerjasama para diakon dengan uskup dalam bingkai Gereja Persekutuan, Laporan Akhir Sinode C.6 juga menyinggung para religius yang terlibat aktif di keuskupan, serta peran para awam dalam kerjasama secara baru dengan para imam. Di antara para awam tersebut, secara khusus disebutkan para perempuan dan orang muda.

Selanjutnya, merujuk pada Seruan Apostolik Paus Paulus VI tahun 1975 tentang tugas penginjilan Evangelii Nuntiandi (EN) 58, Sinode juga berbicara tentang "komunitas-komunitas basis" sebagai realitas baru yang bernilai penting bagi Gereja dalam menghadirkan semangat persekutuan. Dalam Laporan Akhir Sinode C.6 dikatakan: "Karena Gereja adalah persekutuan, "komunitas-komunitas 
basis” yang baru, jika sungguh-sungguh hidup dalam persatuan dengan Gereja, merupakan suatu ungkapan persekutuan yang sejati (a true expression of communion) dan suatu sarana bagi pembangunan persekutuan yang lebih mendalam (a means for construction of a more profound communion), dengan demikian komunitas-komunitas itu menjadi alasan bagi harapan besar untuk kehidupan Gereja (EN 58)” (Extraordinary Synod, 1985).

Dinyatakan bahwa komunitas-komunitas basis, "jika sungguh-sungguh hidup dalam persatuan Gereja”, bernilai positif dan mengungkapkan persekutuan yang sejati. Kata “jika sungguh-sungguh hidup dalam persatuan Gereja” ini, dalam konteks bahasan tentang paroki yang memiliki struktur basis/dasar berupa lingkungan-lingkungan yang melekat utuh pada paroki, sebagaimana dijumpai di Indonesia, misalnya, membuat paroki menjadi tempat komunitas-komunitas itu bertaut dan "hidup dalam persatuan Gereja”.

Pada akhirnya, Laporan Akhir Sinode C.8 memberikan saran-saran atau rekomendasi agar hakikat communio atau persekutuan dapat diimplementasikan lebih luas dalam kehidupan Gereja. Salah satu saran untuk merealisasikan hal itu merujuk pada pidato Paus Pius XII tanggal 20 Februari 1946 (AAS 38, 1946: 144145). Merujuk pendahulunya, yaitu Paus Pius XI yang mengajarkan prinsip subsidiaritas dalam Ensiklik sosial Quadragesimo Anno, Paus Pius XII memandang bahwa prinsip subsidiaritas penting diterapkan dalam kehidupan sosial maupun kehidupan Gereja. Mengikuti Paus Pius XII, Laporan Akhir merekomendasi agar dikaji lebih jauh kemungkinan penerapan prinsip subsidiaritas dalam kehidupan Gereja persekutuan. Sejauh mana prinsip itu dapat diterapkan, dan dalam arti apa penerapan tersebut dapat dan harus dibuat.

Prinsip subsidiaritas sebagai prinsip sosial menyatakan, apa yang bisa dilakukan sendiri dan dengan kekuatan sendiri oleh masing-masing orang, tidak boleh diambil alih dari mereka dan ditangani oleh komunitas. Prinsip ini juga berlaku bagi komunitas-komunitas yang lebih kecil dan dari tingkatan lebih rendah di hadapan komunitas yang lebih besar dari tingkatan lebih tinggi. Subsidiaritas dipegang sebagai prinsip, sebab tiap-tiap kegiatan sosial dari kodratnya bersifat subsidier. Kegiatan itu harus merawat anggota-anggota komunitas, dan tidak menghancurkan atau meniadakan anggota-anggota. Prinsip itu, menurut Paus Pius XII, “sungguh-sungguh membawa terang yang bernilai bagi kehidupan sosial di semua tingkatannya, dan juga bagi kehidupan Gereja, tanpa bias prasangka terhadap struktur hirarkisnya” (AAS 38, 1946: 145).

\subsection{KOMUNITAS BASIS BAGI PERSEKUTUAN: SIGNIFIKANSI}

Seperti dikemukakan, Laporan Akhir Sinode Luarbiasa Uskup 1985 memandang komunitas basis sebagai kenyataan baru yang menumbuhkan harapan besar bagi Gereja, dalam konteks penekanan bahwa eklesiologi persekutuan 
adalah inti eklesiologi Konsili Vatikan II. Berkenaan dengan nilai penting komunitas basis bagi Gereja persekutuan ini Sinode sesungguhnya merujuk pada Seruan Apostolik Paus Paulus VI tentang karya penginjilan di dunia dewasa ini Evangelii Nuntiandi (EN) 1975, art. 58. Seruan ini merupakan refleksi Paus atas pembicaraan Sinode para uskup 1974 tentang karya penginjilan di dunia.

Menurut Paus, komunitas basis merupakan gejala yang sedikit-banyak berkembang di seluruh Gereja. Di satu sisi, komunitas-komunitas ini satu sama lain amat berbeda, baik di dalam wilayah yang sama maupun lebih lagi dari satu wilayah ke wilayah yang lain (AAS 68, 1976: 46). Di sisi lain, dalam kaitan dengan upaya mewujudkan Gereja persekutuan sesuai semangat Konsili, komunitas basis memberikan harapan besar karena komunitas ini "merupakan suatu ungkapan persekutuan yang sejati dan suatu sarana bagi pembangunan persekutuan yang lebih mendalam” (Extraordinary Synod, 1985).

Perspektif persekutuan ini menjadi kriteria bagi eklesialitas atau "kualitas gerejawi” komunitas basis. Komunitas basis layak disebut sebagai komunitas gerejawi terutama karena kontribusinya bagi perwujudan persekutuan. Pertama, karena pada hakikatnya komunitas basis merupakan "suatu ungkapan persekutuan yang sejati”. Kedua, karena komunitas basis mampu berkontribusi secara praktis dalam mewujudkan hakikat Gereja persekutuan di antara umat beriman, yakni sebagai “suatu sarana bagi pembangunan persekutuan yang lebih mendalam”.

Sekaligus bisa dicatat bahwa eklesialitas komunitas basis tersebut, dan dengan demikian validitasnya dalam bingkai kehidupan Gereja, terletak justru pada sakramentalitas yang terdapat pada komunitas basis sebagai realitas gerejawi. Pertama, sebagai "ungkapan”, komunitas basis merupakan "tanda sejati” kehadiran Gereja. Kedua, sebagai “sarana”, komunitas basis sungguh bernilai efektif. Komunitas ini bukan hanya merupakan tanda tetapi sekaligus efektif, berdayaguna (efficax), menghadirkan persekutuan yang ditandakannya.

Kiranya karena alasan teologis inilah Paus memberikan penghargaan yang istimewa pada komunitas basis. Paus menyebut komunitas-komunitas basis ini sebagai penerima Injil dan, sekaligus, penginjil-penginjil itu sendiri. Dikatakan: "Sinode terakhir ini mencurahkan perhatian penuh pada 'komunitas-komunitas kecil' ini, atau disebut dari basis, karena dalam Gereja dewasa ini komunitaskomunitas ini kerapkali dibicarakan. Apakah komunitas-komunitas itu, dan mengapa komunitas-komunitas yang secara istimewa menerima penginjilan ini (evangelizentur) pada yang saat yang sama merupakan penginjil-penginjil itu sendiri (evangelizent)?” (AAS 68, 1976: 46).

Selain memberikan apresiasi terhadap komunitas-komunitas basis, dalam EN 58 Paus juga membuat pembedaan atau penegasan (discernment) terhadap aneka bentuk aktualisasi komunitas basis yang muncul di seluruh dunia. Secara garis besar, Paus membagi komunitas-komunitas basis dalam 2 kelompok. 
Pertama, komunitas-komunitas basis yang sungguh-sungguh gerejawi. Kedua, komunitas-komunitas basis yang sesungguhnya bukan gerejawi, kendatipun komunitas-komunitas itu menyatakan dirinya sendiri sebagai komunitaskomunitas gerejawi (AAS 68, 1976: 47).

Pembedaan ini oleh Paus dikaitkan dengan ada tidaknya tendensi ideologis tertentu dalam komunitas-komunitas itu, yang berakar dari sikap oposisi vis a vis sikap taat pada Gereja. Paus mengatakan:

"Perbedaannya sudah jelas: komunitas-komunitas, yang oleh semangat oposisi mereka, melepaskan diri mereka sendiri dari Gereja dan melukai persatuannya, tidak dapat secara tepat disebut sebagai komunitas basis selain, dalam kasus ini, ini hanyalah suatu nama yang melulu sosiologis. Komunitas-komunitas ini tidak dapat disebut komunitas basis gerejawi tanpa risiko penyalahgunaan istilah, bahkan jika komunitas-komunitas ini menyatakan diri tetap berada dalam persatuan Gereja sembari mengambil sikap bermusuhan terhadap hirarki. Nama ini adalah milik kelompok-kelompok lain, yang hadir bersama dalam Gereja untuk menyatukan diri mereka pada Gereja dan demi mengupayakan pertumbuhan Gereja. Komunitas-komunitas yang terakhir inilah yang akan menjadi tempat penginjilan, bagi manfaat komunitas-komunitas yang lebih besar, khususnya dalam Gereja-gereja partikular” (AAS 68, 1976: 47-48).

Dalam EN 58 Paus merinci manifestasi gejala yang dijumpai pada komunitas-komunitas yang tidak dapat disebut sebagai komunitas basis dalam arti sebenarnya yang sungguh-sungguh gerejawi, karena tendensinya untuk beroposisi secara radikal terhadap Gereja. Paus berkata:

"Di sisi lain, di wilayah-wilayah lain, komunitas basis bersama-sama hadir dalam semangat kritisisme pahit pada Gereja, yang cepat mereka stigmatisasi sebagai 'institusional' dan padanya mereka menempatkan diri sendiri secara bertentangan sebagai komunitas-komunitas karismatis, yang bebas dari struktur-struktur dan diinspirasi hanya oleh Injil. Jadi ciri-ciri jelas pada komunitaskomunitas ini adalah adanya sikap mencari kesalahan dan sikap menolak terhadap wujud-wujud luar berkenaan dengan Gereja: hirarkinya, tanda-tandanya. Komunitaskomunitas itu secara radikal menentang Gereja. Dengan mengikuti garis-garis ini, inspirasi utama mereka dengan amat cepat menjadi ideologis, dan jarang terjadi bahwa mereka tidak segera menjadi kurban pilihan politik atau arus pemikiran tertentu, dan selanjutnya suatu sistem, 
bahkan suatu partai, dengan semua risiko yang menyertai, menjadi alatnya.” (AAS 68, 1976: 47).

Sebaliknya, Paus mencatat adanya komunitas-komunitas yang muncul dan berkembang dalam Gereja, yang memiliki solidaritas dengan kehidupan Gereja, yang tumbuh oleh pengajaran Gereja dan dipersatukan dengan para gembalanya. Paus memaparkan gejala-gejala atau ciri-cirinya:

"Dalam kasus-kasus ini, komunitas-komunitas ini bersumber dari kebutuhan untuk menghidupi kehidupan Gereja secara lebih mendalam, atau dari hasrat dan pencarian akan dimensi lebih manusiawi yang sulit diberikan oleh komunitas-komunitas gerejawi yang lebih besar, khususnya di kota-kota besar modern, yang cocok untuk kehidupan dalam massa dan anonimitas. Komunitaskomunitas ini, dengan cara mereka sendiri, dalam lingkup rohani dan religius, yaitu dalam bakti kepada Allah, pendalaman iman, kasih persaudaraan, doa-doa, dalam persekutuan dengan para gembala, mampu mengembangkan kelompok sosial kecil, suatu kampung dan sebagainya. Atau mungkin juga mereka bermaksud menciptakan kelompokkelompok orang yang berkumpul untuk mendengarkan dan merenungkan Sabda, untuk sakramen-sakramen dan ikatan kasih, berdasar usia, budaya, status kewargaan atau situasi sosial: pasangan perkawinan, orang muda, profesional dan sebagainya; orang-orang yang telah disatukan dalam perjuangan keadilan, bantuan sosial bagi orang miskin, memajukan kemanusiaan. Juga, dalam kasus-kasus lain, komunitas-komunitas ini mengumpulkan orang-orang kristiani di tempat di mana kekurangan imam tidak memungkinkan adanya kehidupan komunitas paroki yang normal. Hal ini sepenuhnya diandaikan dalam komunitaskomunitas yang dibentuk oleh Gereja, khususnya Gerejagereja partikular dan paroki-paroki.” (AAS 68, 1976: 47).

Berdasarkan pemahaman di atas, Paus selanjutnya memberikan kriteria penanda bagi komunitas-komunitas basis yang sungguh menjadi harapan bagi Gereja universal. Dengan hadirnya kriteria itu dalam kehidupan mereka, komunitas-komunitas basis tersebut akan sungguh terhubung dengan panggilan mereka yang paling mendasar, yaitu sebagai pendengar-pendengar Injil yang menerima warta Injil yang disampaikan kepada mereka, sebagai para penerima penginjilan yang istimewa, yang segera akan menjadi pewarta-pewarta Injil itu sendiri (AAS 68, 1976: 49).

Adapun kriteria tersebut adalah: pertama, mengupayakan nutrisi mereka dalam Sabda Allah dan tidak membiarkan diri mereka sendiri terperangkap oleh 
polarisasi politik atau ideologi-ideologi kekinian yang siap mengeksploitasi potensi manusiawi mereka yang besar; kedua, menghindari godaan protes yang sistematis yang terus-menerus hadir, dan sikap kritis yang yang berlebihan, dengan dalih otentisitas dan semangat berkolaborasi; ketiga, tetap teguh menyatukan diri dengan Gereja setempat di mana mereka menjadi bagiannya, dan dengan Gereja universal, dengan demikian menghindari bahaya amat nyata terisolasi dalam diri mereka sendiri, lalu mempercayai diri mereka sendiri sebagai satu-satunya Gereja Kristus sejati, dan dari sini menghakimi komunitas-komunitas gerejawi lainnya; keempat, mengupayakan persekutuan yang tulus dengan para gembala yang diberikan oleh Tuhan kepada Gereja-Nya, dan dengan magisterium yang dipercayakan oleh Roh Kristus kepada para gembala ini; kelima, tidak pernah memandang diri mereka sendiri sebagai satu-satunya penerima atau satusatunya pelaku penginjilan atau bahkan satu-satunya tempat penyimpanan Injil (depository of the Gospel) melainkan karena sadar bahwa Gereja jauh lebih luas dan beraneka, menerima kenyataan bahwa Gereja ini menjadi nyata dengan caracara lain bukan melalui diri mereka sendiri; keenam, terus-menerus tumbuh dalam kesadaran, hasrat, komitmen dan semangat misioner; ketujuh, menunjukkan bahwa diri mereka sendiri universal dalam segala hal dan tidak pernah sektarian (AAS 68, 1976: 48-49).

Dari keseluruhan pembahasan tampak bahwa kriteria bagi komunitas basis sejati seperti dijelaskan oleh Paus mengandaikan adanya kesatuan tak terpisahkan antara komunitas-komunitas basis dengan Gereja, dengan para gembala dan aneka komunitas lain dalam pelbagai macam bentuk dan aspek kehidupannya dalam Gereja lokal maupun universal. Kesatuan ini, atau dalam terminologi Sinode Luarbiasa Uskup 1985 “persekutuan”, dengan demikian menjadi kriteria kunci bagi kualitas atau status gerejawi, atau eklesialitas, komunitas-komunitas basis.

Dengan mengandaikan adanya persatuan dengan Gereja sebagai kriteria kesejatian, dimensi "harapan" berkenaan dengan masa depan Gereja sebagai persekutuan dalam kehidupan umat justru amat bertumpu pada keberadaan dan perkembangan komunitas-komunitas basis dalam Gereja partikular, di parokiparoki. Di dalam komunitas-komunitas ini otentisitas pengalaman iman dan mendengarkan Sabda dalam persekutuan dapat berlangsung lebih intensif. Dengan kehidupan bersama di antara para warganya, hal-hal hakiki yang diharapkan terwujud dalam Gereja dapat ditemukan aktualisasinya secara konkret dan mendalam di tingkat akar rumput dalam komunitas-komunitas ini.

\subsection{MUPAS II, KONSILI VATIKAN II DAN AJARAN SESUDAHNYA: KETERHUBUNGAN}

Studi ini ingin mendalami gagasan "paroki berakar lingkungan” dalam Mupas II dan bagaimana gagasan ini diletakkan dalam perspektif Konsili Vatikan 
II dan ajaran sesudahnya. Pendekatan ini ingin membantu melihat dalam hal apa dan sejauh mana perjalanan pastoral Keuskupan Surabaya, sejak Pola Pastoral Berbasis Persekutuan tahun 2008 dan Mupas I tahun 2009 serta Mupas II tahun 2019, terhubungkan dengan refleksi Gereja universal tentang kehadirannya di dunia secara konkret-nyata.

Pada dokumen Konsili Vatikan II, terdapat gambaran jelas tentang nilai penting paroki dalam penggembalaan uskup melalui para pastor paroki, dan dalam kehidupan Gereja secara universal sebagai kesaksian bagi dunia. Paroki sendiri didirikan agar tugas penggembalaan uskup terhadap seluruh kawanannya dapat dilaksanakan. Karena besarnya jumlah kawanan dan tersebarnya keberadaan mereka, uskup tidak dapat memimpin kawanan itu secara sendirian. Maka uskup menyertakan pastor paroki, yang di paroki masing-masing berperan sebagai gembala khusus bagi umat (pastor proprius) yang dipercayakan kepadanya. Di sini kita berbicara secara khusus tentang fungsi pastoral paroki.

Namun selain fungsi pastoral, paroki juga menyandang fungsi representasi. Dengan fungsi ini, paroki berperan sebagai wakil seluruh Gereja universal dalam kehadirannya di dunia. Paroki menjadi wajah nyata persekutuan, tanda dan sarana Gereja sedunia untuk hadir di tengah masyarakat sekitar. Hal ini dikerjakan oleh paroki dalam segala aktivitasnya, di bidang peribadatan, pewartaan, pelayanan ataupun kesaksian iman terhadap siapapun juga.

Dalam pembahasan “paroki berakar lingkungan”, terdapat beberapa hal yang berkaitan dengan fungsi-fungsi paroki menurut Konsili di atas, yang layak lebih jauh direfleksikan. Refleksi ini penting khususnya ketika dikaitkan dengan kedudukan lingkungan sebagai “akar paroki”.

Pertama, ditinjau dari segi pastoral, pilihan Mupas II untuk memberi perhatian utama pada paroki tentu merupakan pilihan yang tepat. Perhatian pada penggembalaan umat memang mengharuskan adanya perhatian pada parokiparoki, karena umat beriman terutama ada di paroki-paroki. Dengan memberi perhatian pada paroki, maka kita memberi perhatian pada karya penggembalaan yang diemban oleh uskup bagi seluruh umat yang menjadi tanggung jawabnya.

Kedua, terkait dengan fungsi representasi paroki sebagai kehadiran seluruh Gereja di masyarakat secara langsung dan nyata, perhatian Mupas II pada paroki bernilai penting karena langsung berkaitan dengan persoalan kehadiran Gereja di masyarakat. Melalui paroki Gereja hadir secara langsung dan nyata di masyarakat. Maka perhatian pada paroki bermakna perhatian pada tugas perutusan Gereja di masyarakat, untuk menjadi tanda dan sarana keselamatan bagi dunia.

Ketiga, fungsi pastoral paroki bagi keuskupan dan fungsi representasinya bagi Gereja universal dapat dilihat penerapannya pada lingkungan sebagai akar paroki dan unit terkecil dalam pola pastoral berbasis persekutuan di keuskupan. Hal ini dapat dijabarkan sebagai berikut. 
Bagi paroki, lingkungan berfungsi pastoral karena dengan cara itulah umat yang berjumlah banyak dan tersebar keberadaannya dapat digembalakan dengan baik oleh pastor paroki. Demikian pula, lingkungan berfungsi representasi karena kehadirannya di tengah masyarakat merupakan kehadiran Gereja itu sendiri.

Karena lingkungan merupakan bagian utuh dalam struktur keuskupan, maka lingkungan hadir sebagai wakil, representasi dan wajah keuskupan. Melalui lingkungan-lingkungan yang hadir di tengah-tengah masyarakat sekitarnya, Gereja keuskupan sebagai satu keutuhan sungguh nyata dirasakan.

Gambaran ini selaras dengan Pedoman Pastoral Pengurus Lingkungan Pasal 4, yang membahas mengenai 3 fungsi lingkungan. Dua fungsi lingkungan yang pertama berdimensi internal, bersifat pastoral, yaitu: lingkungan berfungsi menghidupi dan menghidupkan iman warganya, dan lingkungan berfungsi meneguhkan iman dan menopang persekutuan Gereja paroki. Selanjutnya, fungsi ketiga lingkungan berdimensi eksternal, dan dapat disejajarkan dengan fungsi wakil atau representasi Gereja yang diemban oleh paroki, yaitu fungsi untuk meresapi dan meresapkan nilai-nilai Injil di tengah masyarakat, sehingga Injil menjadi daya hidup masyarakat (Seri MUPAS Buku 4, 2019: 17).

Keempat, hal lain yang perlu digarisbawahi adalah relasi lingkungan dengan paroki dan pastor paroki. Relasi ini dapat direfleksikan dengan mengacu pada penegasan Konsili tentang prinsip relasi paroki-paroki dengan uskup dan seluruh keuskupan. Termasuk dalam prinsip ini bahwa pastor paroki merupakan partisipan dalam karya penggembalaan uskup. Berdasarkan prinsip ini, pengurus lingkungan harus dimaknai sebagai orang-orang yang ambil bagian dalam tugas pastoral pastor paroki terhadap umat di lingkungannya yang, sebagai umat paroki, dipercayakan oleh uskup kepada pastor paroki. Karena pastor paroki tidak dapat menggembalakan seluruh umat secara sendirian, maka dibutuhkan rekan-rekan kerja yang langsung mendampingi mereka dalam lingkungan.

Di tinjau dari perspektif ini, relasi iman dalam Kristus dan kesatuan karya penggembalaan di antara para pengurus lingkungan dan antara mereka dengan seluruh perangkat pastoral di bawah kepemimpinan pastor paroki dan dalam persatuan dengan uskup adalah bagian utuh dan intrinsik dari gagasan "paroki berakar lingkungan”. Di balik gagasan “paroki berakar lingkungan”, terdapat prinsip persekutuan Gereja secara universal, yang menghubungkan semua orang beriman dengan Allah dan sesama, yang diaplikasikan di tingkat keuskupan.

Dalam bingkai ini pula kita memahami penegasan tentang peran awam dalam tugas-tugas pastoral uskup dan para imam seperti dinyatakan oleh Apostolicam Actuositatem, dan implikasinya bagi kepengurusan lingkungan. Imam secara pastoral ikut serta dalam keprihatinan uskup dan tergabung dengannya dalam satu presbyterium, dan para awam ambil bagian dalam dinamika partisipasi itu sesuai dengan kekhasan mereka, sampai di tingkat 
lingkungan. Dengan cara ini paroki, sebagai sel keuskupan, sungguh hadir sebagai organisme yang hidup dan dinamis, terutama karena lingkungan-lingkungannya sungguh-sungguh hidup, terhubung nyata dengan keuskupan berkat komunikasi, koordinasi dan kerja sama para pengurus lingkungan dengan pastor paroki.

Sinode Luarbiasa Uskup 1985 menggarisbawahi eklesiologi persekutuan sebagai gagasan sentral eklesiologi Konsili Vatikan II. Usaha Konsili adalah “agar Gereja sebagai persekutuan dapat lebih jelas dipahami dan lebih konkret diwujudkan dalam kehidupan” (Extraordinary Synod, 1985). Dari perspektif ini, pembahasan tentang paroki sebagai pengemban fungsi pastoral uskup dan representasi Gereja universal di tengah masyarakat juga harus diletakkan dalam rangka perwujudan persekutuan dalam kehidupan yang nyata. Dalam perspektif ini pula lingkungan harus diletakkan, yaitu sebagai upaya mewujudkan persekutuan dalam kehidupan nyata, khususnya pada tingkat akar rumput.

Sebagaimana diketahui, di Keuskupan Surabaya sendiri dicanangkan Pola Pastoral Berbasis Persekutuan pada tahun 2008. Pola ini mendapat peneguhan dalam Mupas I, yang merumuskan Arah Dasar Keuskupan. Arah Dasar ini dalam Mupas II diuraikan lebih lanjut dalam 48 butir penjelasan atas 5 kata kunci yang terdapat di dalamnya, yaitu "kemuridan” "persekutuan”, “kedewasaan iman”, “guyup dan penuh pelayanan” serta "misioner”. Dengan demikian "persekutuan” telah menjadi kata kunci dalam karya pastoral Keuskupan Surabaya sejak 10 tahun lebih, dan akan berlanjut setidaknya dalam 10 tahun ke depan ini.

Dalam konsep Pola Pastoral Berbasis Persekutuan ini, terdapat 2 basis persekutuan yang saling melengkapi agar persekutuan dapat sungguh-sungguh terealisasi. Pertama, "basis perwujudan”, dan kedua, "basis koordinasi”. Kedua basis tersebut masing-masing terdapat di tingkat keuskupan dan di tingkat paroki.

Di tingkat keuskupan, basis perwujudan persekutuan adalah paroki, dan basis koordinasinya adalah kevikepan. Diupayakan agar persekutuan dapat terwujud nyata di tingkat basis, yaitu di setiap komunitas paroki yang tersebar di seluruh keuskupan. Kevikepan berfungsi koordinatif agar paroki-paroki di wilayah kevikepan dapat saling berbagi, menguatkan dan memperoleh dukungan satu sama lain dalam upaya mereka bersama-sama membangun persekutuan yang utuh dan kuat di tingkat keuskupan. Perangkat pastoral Keuskupan berfungsi mendorong, memberi animasi dan bantuan agar semua dinamika di tingkat paroki dan kevikepan dapat berlangsung dengan baik dan efektif.

Di tingkat paroki, basis perwujudan persekutuan adalah lingkungan, dan basis koordinasinya adalah wilayah. Yang menjadi prioritas adalah bagaimana persekutuan dapat terwujud nyata di tingkat basis, yaitu di setiap komunitas lingkungan yang ada di paroki. Wilayah berfungsi koordinatif, agar lingkunganlingkungan dapat memperoleh dukungan, saling belajar dan menguatkan dalam upaya mereka bersama-sama membangun persekutuan yang kuat dan utuh di 
tingkat paroki. Dalam hal ini, perangkat pastoral paroki berfungsi memberikan dorongan dan bantuan agar dinamika persekutuan di tingkat lingkungan dan koordinasi di wilayah-wilayah dapat berlangsung baik dan efektif.

Dengan pola ini lingkungan ditempatkan sebagai basis perwujudan persekutuan di tingkat paroki, seperti halnya paroki merupakan basis perwujudan persekutuan di tingkat keuskupan. Sementara itu wilayah dalam paroki dijadikan basis koordinasi lingkungan-lingkungan untuk membangun persekutuan di tingkat paroki, seperti halnya kevikepan ditempatkan sebagai basis koordinasi parokiparoki untuk membangun persekutuan di tingkat keuskupan.

Ditinjau dari perspektif konsep pola pastoral ini, kebijakan strategis pastoral Mupas II 2019 dalam menempatkan lingkungan sebagai akar paroki menunjukkan adanya kesinambungan dan kesatuan dengan kebijakan periode sebelumnya. Pada periode Mupas I perhatian pastoral lebih tertuju pada penguatan paroki-paroki sebagai basis perwujudan persekutuan tingkat keuskupan, dan untuk mendukung paroki-paroki, kevikepan ditempatkan sebagai basis koordinasi. Jika kini pada periode Mupas II perhatian tertuju pada lingkungan sebagai basis perwujudan persekutuan tingkat paroki, kiranya wilayah akan dijadikan sebagai basis koordinasi untuk menguatkan lingkungan-lingkungan. Tujuan akhirnya tentu agar persekutuan umat di keuskupan dapat kian terwujud nyata.

Ditinjau dari segi ini jelas pula bahwa kebijakan pastoral strategis Mupas II, “paroki berakar lingkungan yang hadir di tengah masyarakat” merupakan bentuk penerapan Pola Pastoral Berbasis Persekutuan, yang ditempuh melalui penguatan persekutuan paroki sejak dari tingkat akar rumput, yaitu dari lingkungan-lingkungan yang dimilikinya. Sinode Luarbiasa Uskup-uskup tahun 1985 menyatakan bahwa persekutuan atau koinonia “didasarkan pada Kitab Suci, dipegang penuh hormat di Gereja kuno dan di Gereja-gereja Timur hingga sekarang”. Maka, dalam konteks pastoral Gereja Keuskupan Surabaya, dapat dikatakan pula bahwa upaya membangun persekutuan di tingkat akar rumput dalam semangat Mupas II merupakan bentuk perwujudan atas cita-cita Konsili itu, "agar Gereja sebagai persekutuan dapat lebih jelas dipahami dan lebih konkret diwujudkan dalam kehidupan” (Extraordinary Synod, 1985).

Karena Gereja hakikatnya adalah persekutuan, Sinode Luarbiasa 1985 menghendaki, "harus ada partisipasi dan tanggungjawab bersama (participation and co-responsability) di semua jenjangnya. Prinsip umum ini harus dimengerti dalam beraneka cara di berbagai area”. Dengan kata partisipasi dan tanggung jawab bersama, Sinode menyinggung peran para imam dalam menghadirkan uskup di setiap komunitas umat beriman, dan menjalankan tugas dan keprihatinan uskup dalam pekerjaan harian mereka. Selain itu juga disinggung peran para religius dan awam. Di antara para awam, termasuk perempuan dan orang muda (Extraordinary Synod, 1985). Dalam konteks kebijakan strategis pastoral "paroki 
berakar lingkungan”, kiranya ini berarti bahwa setiap insan beriman dipanggil untuk ambil bagian menguatkan lingkungan sebagai akar persekutuan paroki dengan aneka cara yang mungkin dilakukan oleh mereka. Dengan cara ini, upaya mewujudkan persekutuan menjadi upaya semua anggota Gereja. Di masa depan, kiranya upaya lebih konkret perlu dilakukan agar harapan Sinode ini mendapatkan wujud nyata, khususnya dalam dinamika persekutuan lingkungan.

Perhatian Sinode Luarbiasa 1985 terhadap peran penting komunitas basis gerejawi (KBG) dalam mewujudkan hakikat Gereja persekutuan, sambil mengutip seruan apostolik Paus Paulus VI Evangelii Nuntiandi 58, kiranya harus dipandang pula sebagai bentuk perhatian bahkan apresiasi terhadap kehadiran lingkungan dalam paroki. Dengan semua aspek yang telah diungkapkan tentang lingkungan dalam Mupas II, juga berdasarkan riwayat kemunculan lingkungan dalam sejarah Gereja di Indonesia, jelas bahwa lingkungan merupakan cara hidup menggereja kelompok kecil umat di tingkat basis atau akar rumput yang khas Indonesia, juga khas keuskupan Surabaya, namun sungguh memenuhi kriteria kegerejawian yang telah digariskan oleh Paus Paulus VI dalam Evangelii Nuntiandi 58.

Pertama, karena dari segi dinamika anggota lingkungan, lingkungan oleh para warganya dihayati sebagai cara menggereja, yaitu menghidupi dan menghidupkan persekutuan, peribadatan, pewartaan sabda, pelayanan sesama dan kesaksian iman, yang merupakan tugas-tugas setiap warga Gereja. Para anggotanya hidup bersaudara dan saling menguatkan iman.

Kedua, karena dari segi kehadirannya di tengah masyarakat, lingkungan sebagai kebersamaan para warga Katolik menjadi sarana kehadiran Gereja bagi masyarakat dalam lingkup wilayahnya. Masyarakat mengenal kekatolikan, cara hidup kelompok khas murid-murid Kristus. Kelompok ini tampak menghayati imannya sebagai kawanan tersendiri, tetapi jelas mempunyai keterbukaan dalam sikap dan peran di dalam kehidupan mereka. "Kegembiraan dan harapan, duka dan kecemasan" masyarakat sekitar lingkungan juga menjadi "kegembiraan dan harapan, duka dan kecemasan” orang-orang Katolik warga lingkungan.

Ketiga, yang menjadi penentu karakter kegerejawian lingkungan adalah bahwa lingkungan sebagai entitas kehidupan merupakan bagian utuh kehidupan Gereja secara keseluruhan yang tak terpisahkan. Lingkungan adalah bagian utuh paroki, terlibat langsung dalam kehidupan paroki, menyemarakkan suasana paroki, baik dalam hal peribadatan, pelayanan sosial maupun dalam berbagai aspek persekutuan. Sebagai bagian utuh paroki, lingkungan secara langsung juga merupakan bagian utuh keuskupan. Hal itu terjadi terutama karena keterikatan setiap warga dan seluruh lingkungan dengan uskup sebagai gembala mereka, dan relasi mereka yang tak terputus dengan pastor paroki sebagai wakil uskup di parokinya. Dengan cara itu lingkungan, dengan hadir di masyarakat, menjadi wajah Gereja keuskupan yang dapat dirasakan langsung oleh masyarakat. 
Dengan gambaran di atas, maka secara umum dapat dikatakan bahwa terdapat keterhubungan yang kuat dan jelas antara dinamika pastoral yang tengah berlangsung di Keuskupan Surabaya dan pemahaman serta harapan para gembala Gereja universal tentang hakikat Gereja dan bagaimana hal itu diwujudkan dalam Gereja-gereja lokal. Keterhubungan itu terdapat pada prinsip persekutuan, yang di dalam dinamika pastoral Keuskupan diusahakan perwujudan konkretnya, bukan hanya pada tataran permukaan atau institusional, tetapi lebih mendalam, di dalam kehidupan iman umat, hingga menyentuh aspek keseharian mereka di masyarakat. Jalur yang ditempuh untuk mewujudkan prinsip itu adalah paroki dan lingkungan. Maka, jika dalam Mupas II ini Keuskupan Surabaya secara sadar telah mengambil kebijakan strategis pastoral "dalam semangat Ardas mendewasakan paroki berakar lingkungan yang hadir di tengah masyarakat”, selanjutnya yang penting adalah usaha nyata agar kebijakan itu dalam perjalanan Keuskupan 10 tahun ke depan dapat terwujud dengan baik, membuahkan hasil yang bermutu.

\section{KESIMPULAN DAN SARAN}

Studi tentang kebijakan strategis pastoral Keuskupan Surabaya hasil Mupas II, "mendewasakan paroki berakar lingkungan yang hadir di tengah masyarakat”, khususnya dengan fokus tentang "paroki berakar lingkungan” terdapat gambaran yang kuat dan jelas tentang keterhubungan antara dinamika pastoral Keuskupan Surabaya dan apa yang diharapkan oleh Gereja universal. Dokumen-dokumen Konsili Vatikan II dan sesudahnya memberikan kerangka pemahaman tentang "paroki”, "persekutuan” dan "komunitas basis gerejawi” (KBG) yang wujud implementasinya dapat ditemukan dalam dinamika pastoral Keuskupan, baik yang telah berjalan, maupun yang direncanakan di masa depan.

Mupas II sendiri menyatakan bahwa kebijakan "merawat dan memelihara akar” dalam bingkai "paroki berakar lingkungan yang hadir di tengah masyarakat” berkonsekuensi pada 4 hal sebagai tindak lanjut. Pertama, "Kita perlu perubahan paradigma dari pastoral berpusatkan paroki ke pastoral berakar lingkungan”. Kedua, "Kita perlu memperhatikan secara seksama karakteristik sosial-ekonomipolitik-geografis-budaya lingkungan dan masyarakat. Ketiga, "Kita perlu membaca trend atau pola tantangan dalam masyarakat sebagai fenomena umum yang ditangkap dalam pengalaman pastoral para imam dan membutuhkan masukan dari para pakar”. Keempat, "Kita perlu bekerja keras menyiapkan perangkat dan media untuk merawat” (Seri MUPAS Buku 2, 2019: 18).

Empat hal tersebut kiranya perlu dijabarkan lebih lanjut ke dalam berbagai aspek kehidupan paroki dan lingkungan. Misalnya di bidang struktur organisasi pastoral paroki, juga dalam hal isi dan bentuk katekese atau pengajaran. Juga perlu disertakan kajian lapangan dalam menyusun kebijakan dan program tingkat paroki, yang akan berdampak bagi pengembangan lingkungan-lingkungan di 
paroki. Perlu dihindari generalisasi yang mengabaikan kekhasan kondisi sosial lingkungan-lingkungan dalam paroki. Juga diperlukan pencermatan terhadap perkembangan yang terjadi di masyarakat, yang mungkin luput dari pengamatan sehari-hari. Untuk itu diperlukan konsultasi dan masukan dari unsur-unsur umat, baik individu ataupun institusi, yang terlibat langsung dalam gerak kehidupan di masyarakat. Juga diperlukan kerja-kerja tersendiri yang melibatkan aneka pihak untuk melengkapi proses penguatan lingkungan dengan mengadakan berbagai sarana maupun program pembinaan yang bisa langsung menyentuh umat.

Terakhir, perkembangan masyarakat, khususnya akibat pandemi Covid-19, menuntut timbulnya kesadaran baru tentang tantangan-tantangan pastoral, dan upaya baru dan lebih besar, bahkan rintisan, yang sebelumnya belum ada atau belum pernah dilakukan, agar nilai-nilai hakiki persekutuan di paroki dan di lingkungan-lingkungan tetap terpelihara baik. Selain membuka kemungkinan menggunakan sarana, media atau metode baru, juga perlu dibuka kemungkinan melibatkan orang-orang baru, yang mungkin selama sekian waktu tidak aktif dalam kehidupan lingkungan. Menjadi sangat menarik jika upaya-upaya ini nantinya justru memberi warna baru dan lebih hidup dalam menggereja dengan cara berlingkungan, sebagai akar paroki yang hadir di tengah masyarakat.

\section{DAFTAR PUSTAKA}

---------, AAS 56, 1964 (memuat Sacrosanctum Concilium).

--------, AAS 57, 1965 (memuat Lumen Gentium).

--------, AAS 58, 1966 (memuat Christus Dominus, Apostolicam Actuositatem).

--------, AAS 68, 1976 (memuat Evangelii Nuntiandi).

--------, Seri MUPAS Buku 1, 2019. Arah Dasar Keuskupan Surabaya Tahun 2020-2030, Keuskupan Surabaya, Surabaya.

---------, Seri MUPAS Buku 2, 2019. Kebijakan Pastoral Strategis Keuskupan Surabaya Tahun 2020-2030, Keuskupan Surabaya, Surabaya.

--------, Seri MUPAS Buku 3, 2019. Program Strategis Keuskupan Surabaya Tahun 2020-2030, Keuskupan Surabaya, Surabaya.

---------, Seri MUPAS Buku 4, 2019. Pedoman Pastoral Pengurus Lingkungan Keuskupan Surabaya Tahun 2020-2030, Keuskupan Surabaya, Surabaya.

--------, 2012. Pedoman Dasar DPP-BGKP Keuskupan Surabaya, Surabaya.

Extraordinary Synod, 1985, The Final Report (Laporan Akhir Sinode), https://www.ewtn.com/catholicism/library/final-report-of-the-1985extraordinary-synod-2561 